Asian J. Med. Biol. Res. 2020, 6 (4), 635-640; doi: 10.3329/ajmbr.v6i4.51229

\author{
Asian Journal of \\ Medical and Biological Research \\ ISSN 2411-4472 (Print) 2412-5571 (Online) \\ www.ebupress.com/journal/ajmbr
}

\title{
Article \\ Effects of bisphenol-A (BPA) on body weight, hematological parameters and histo- texture of kidney in swiss albino mice
}

Emdadul Hoque, Khaled Mahmud Sujan, Md. Suman Mia, Md. Iqramul Haque, Afrina Mustari, Mohammad Alam Miah and Md. Kamrul Islam*

Department of Physiology, Faculty of Veterinary Science, Bangladesh Agricultural University, Mymensingh2202, Bangladesh

*Corresponding author: Professor Dr. Md. Kamrul Islam, Department of Physiology, Faculty of Veterinary Science, Bangladesh Agricultural University, Mymensingh-2202, Bangladesh. Phone: +8801715414007 ; Email: k.physiol@bau.edu.bd

Received: 16 October 2020/Accepted: 24 November 2020/ Published: 31 December 2020

\begin{abstract}
Bisphenol-A (BPA) is one of the highest volume chemicals produced world-wide and used in the manufacture of plastics and epoxy resins that are pervasive in our environment and daily lives. The present research was carried out to investigate the effects of two different doses of Bisphenol-A (BPA) on the body weight, hematological parameters and patho-physiological changes of kidney in mice. For this study, fifteen mice, 6 to 8 weeks of age with an average bwt $27.10 \pm 0.5 \mathrm{gm}$, were randomly divided into three groups $(\mathrm{n}=5)$. Group A (control) received only normal mouse pellet while group B and group C received pellet mixed with BPA @ $50 \mathrm{mg}$ and $100 \mathrm{mg} / \mathrm{kg}$ bwt daily for 12 weeks, respectively. At the end of the experiment, blood and tissues were collected and processed for hematological and histopathological examination. Results showed that BPA- treated mice caused significant elevation $(\mathrm{p}<0.01)$ in weight gain even treated with low dose $(50 \mathrm{mg})$ of BPA. The mice exposed to high dose of BPA $(100 \mathrm{mg})$ showed marked reduction $(\mathrm{p}<0.05)$ in total erythrocyte count (TEC), significant decreased $(\mathrm{p}<0.01)$ in hemoglobin concentration $(\mathrm{Hb})$ and packed cell volume $(\mathrm{PCV})$. Histopathological alterations were detected in the kidneys of BPA-treated mice. In conclusion, this study suggested that BPA exerts deleterious impacts on hematological parameters including association with renal injuries.
\end{abstract}

Keywords: bisphenol-A; TEC; Hb; PCV; mice; kidney

\section{Introduction}

Bisphenol-A (BPA) is a high molecular polymer compound that generally used in the manufacture of polycarbonate plastic, water and baby bottles, epoxy resins, inside coating of food cans and dental sealants (Hernandez- Rodriguez et al., 2007). BPA is one of the highest volume industrial chemicals produced and global consumption of BPA in 2011 was predicted to exceed 5.5 million metric tons (Greiner et al., 2007). It is a pseudo-persistent chemical, which despite its short half-life is ubiquitous in the environment because of continuous release (Oehlmann et al., 2009). BPA has been detected in drinking water and food of humans and animals due to ubiquity use of plastic products (Michalowicz, 2014). BPA is released by food and beverage containers (El-Missiry et al., 2014) and route of exposure is ingestion, inhalation and skin penetration (Rubin, 2011). The range of BPA levels found in humans is from 0.7 to $20 \mathrm{nM}$ (vomSaal et al., 2007). The perinatal and postnatal exposure of BPA to mice may be involved in the development of obesity and/or hyperlipidemia (Miyawaki et al., 2007). The risk of developing type 2 diabetes mellitus, hypertension, and dyslipidemia increases due to environmental estrogen exposure. (Alonso-Magdalena et al., 2006). Bisphenol-A is targeted at multiple organs such as kidneys, liver, spleen, pancreas and lungs (Petteri, 2002). 100g/kg/day dose of BPA can cause dilation and propagation of glomeruli and degeneration of epithelium of proximal tubule in kidney. (Rahimi et al., 2015). However, to our knowledge there is few researches have done about BPA in Bangladesh. 
Therefore, the proposed work was carried out to fulfill the following objectives: to assess the effect of different doses of Bisphenol-A (BPA) on body weight gain, Total Erythrocyte Count, Hemoglobin, Packed Cell Volume, Erythrocyte Indices and histo-texture of kidney.

\section{Materials and Methods}

\subsection{Experimental animals}

To run the study, mice were purchased from International Center for Diarrheal Disease Research, Bangladesh (icddr,b), Mohakhali, Dhaka. Before being mice used in this experiment, they were kept for 7 days in order to adjust to the new environment. They were reared in a compartmentalized square wooden cages $(9 \times 11 \times 7$ cubic inches) wrapped with wire mesh under controlled conditions of temperature (26-30) ${ }^{\circ} \mathrm{C}$ and relative humidity of $70-80 \%$ with natural day light.

\subsection{Experimental chemical}

Bisphenol-A (BPA) was purchased from Sigma-Aldrich Company, USA and was dissolved in sunflower oil (vehicle) as stock before administration. BPA was handled cautiously to avoid the chance to get exposed to it.

\subsection{Ethical approval}

The present study and all experimental procedures were approved and performed according to the guidelines for the care and use of animals as established by Animal Welfare and Experimentation Ethics Committee, Bangladesh Agricultural University, Mymensingh.

\subsection{Experimental design}

The experiment was conducted at the Department of Physiology, Bangladesh Agricultural University, Mymensingh, from February to April 2018. In this study, total 15 female Swiss Albino mice (Mus musculus) aged between $6-8$ weeks with an average body weight of $27.10 \pm 0.5 \mathrm{gm}$ were used. The mice were randomly divided into three groups, each consisted of five mice. Group A served as control provided only basal mouse pellet mixed with sunflower oil, on the other hand, Group B and Group C received basal pellet mixed with formulated sunflower oil (as vehicle for BPA) containing two different doses of BPA @ $50 \mathrm{mg}$ and $100 \mathrm{mg} / \mathrm{kg}$ body weight daily for 12 weeks, respectively.

\subsection{Management practices}

In order to keep feed fresh and prevent spoilage, feeds were kept in air tight feed container. The feed was supplied three times daily to the mice and fresh drinking water was made available for 24 hours. Cages were cleaned regularly. Proper hygienic and sanitary measures were also tightly adopted during the experimental period. With the help of a digital balance, the initial body weight of each mouse was measured. Body weight was measured at first day and then every 7 days' intervals until end of the experiment.

\subsection{Collection of blood}

At the end of the experiment ( $12^{\text {th }}$ week), blood samples were collected by sacrificing the mice. The mice were kept fasting overnight. Then the mice were placed one by one in an airtight container containing diethyl ether presoaked cotton. They were checked for unconsciousness. The mice were taken out from the airtight container and blood was collected directly from heart by a sterile syringe. About 1 to $1.5 \mathrm{ml}$ blood was collected from each mouse.

\subsection{Hematological parameters}

Hemoglobin concentration ( $\mathrm{Hb}$ conc.), packed cell volume (PCV) and total erythrocyte count (TEC) were preformed as per standard method proposed by (Ghai, 2013). The RBC indices measure the size, shape, and physical characteristics of the RBCs. It is the size and hemoglobin contain of erythrocytes that can be determined by calculating the values obtained from TC of RBC in million/cubic mm, $\mathrm{Hb}$ concentration in gm \% and PCV in \%. All of the hematological parameters were done at the Department of Physiology, Bangladesh Agricultural University, Mymensingh.

\subsection{Histopathology}

The kidney from each group of mice were collected after completely removal of blood by perfusion with phosphate buffered saline and kept in 10\% neutral buffered formalin for 15 days. The well fixed tissues were processed, sectioned and stained as per standard procedure (Banchroft et al., 1996) in collaboration with the 
Department of Pathology, Mymensingh Medical College, Mymensingh. The stained slides were observed under Optika Vision Lite 21 and photographs of the characteristic findings were recorded. Histologically, the degenerative lesions of kidney in all groups of experimental mice were graded as mild (+), moderate (++) and severe $(+++)$.

\subsection{Statistical analysis}

All data were subjected to statistical analysis using SPSS program by one-way ANOVA followed by post-hoc Turkey's test.

\section{Results and Discussion}

\subsection{Effect of varying concentration of BPA on body weight gain in mice}

Average body weight gain in mice upon treated with two different doses of BPA is shown in Table 1. Mice treated with both BPA $50 \mathrm{mg}$ and BPA $100 \mathrm{mg}$ showed that there was significant $(\mathrm{p}<0.01)$ increased in the body weight of mice at $6^{\text {th }}$ and $12^{\text {th }}$ week compared with the control group respectively. Body weight at $3^{\text {rd }}$ week $(p<0.05)$ and $9^{\text {th }}$ week $(p<0.01)$ were significantly increased in mice treated with BPA $100 \mathrm{mg}$ compare to that of control group. The present findings are closely related with the findings of Miyawaki et al. (2007); Newbold et al. (2008) and Rubin and Suto, 2009 and they reported that BPA has a great influenced on body weight gain by fat accumulation, facilitates gluconeogenesis, adiponectin secretion and adipocyte differentiation.

\subsection{Effect of varying concentration of BPA on blood parameters in mice}

Mice treated with BPA $50 \mathrm{mg}$ exhibited no significant reduction in Hb concentration, TEC and PCV compared to control group (Table 2). On the other hand, $\mathrm{Hb}$ concentration and PCV of BPA $100 \mathrm{mg}$ exposed mice were significantly reduced $(\mathrm{p}<0.01)$ compared to control while TEC of BPA $100 \mathrm{mg}$ treated mice was significantly decreased $(\mathrm{p}<0.05)$ with comparison to control respectively. In case of RBC indices, MCV and MCHC of both BPA $50 \mathrm{mg}$ and BPA $100 \mathrm{mg}$ treatment group and $\mathrm{MCH}$ of BPA $50 \mathrm{mg}$ treatment group showed no significant reduction compared to control group (Table 2). Only the MCH of BPA $100 \mathrm{mg}$ treatment group increased significantly $(\mathrm{p}<0.01)$ compared to control group. The present findings come in accordance with Ahmed et al. (2015), Samie et al. (2017) and Yamasaki and Okuda (2012) and they found that BPA induced a significant decrease in red cell count, $\mathrm{Hb}$ concentration and PCV. BPA may inhibit the synthesis of hemoglobin or lysis of $\mathrm{RBC}$ or alter the structure of hemoglobin which may affect the physiological functions of hemoglobin (Fang $e t$ al., 2011; Uluta et al., 2011). Bisphenol-A causes a significant decrease in viability, osteogenic differentiation in the bone marrow mesenchymal stem cells and abnormal development in bone leads to production of insufficient RBC (Azimin et al., 2013).

\subsection{Effect of BPA on histo-structure of kidney in mice}

Section of kidney of non-treated mice showed normal tissue structures and no remarkable changes were found (Figure 1). Mice treated with BPA $50 \mathrm{mg}$ showed that hemorrhage in the renal tubules and moderate loss of lining epithelium cells of the renal tubules (++) whereas mice treated with BPA $100 \mathrm{mg}$ showed that severe loss of lining epithelium cells of the renal tubules (+++) (Figure 1). There are similarities between the renal alteration detected in this study and those described by previous authors (Hassan et al., 2012; Yildiz and Barlas, 2013; Nakagawa and Tayama, 2000). Bisphenol-A has a nephrotoxic effect due to accumulation of BPA toxic metabolites and inability of the kidney to eliminate those substances (Sangai et al., 2012; Korkmaz et al., 2010). The organization of the urinary tubules and seminiferous tubules of the kidney was found altered upon treated with BPA (Roig et al., 2014; Geetharathan and Josthna, 2016). They observed that distribution of BPA at dose $500 \mathrm{mg} / \mathrm{kg} / \mathrm{day}$ for 15 days caused significant increasing in serum urea and creatinine levels, suggesting an impairment of renal function.

Table 1. Comparison of average body weight gain in different treatment groups of mice.

\begin{tabular}{|l|l|l|l|l|l|}
\hline Parameters & $\begin{array}{l}\text { Initial body } \\
\text { weight }(\mathbf{g})\end{array}$ & $\begin{array}{l}\text { Body weight at } \\
\mathbf{3}^{\text {rd }} \text { week }(\mathbf{g})\end{array}$ & $\begin{array}{l}\text { Body weight at } \\
\mathbf{6}^{\text {th }} \text { week(g) }\end{array}$ & $\begin{array}{l}\text { Body weight at } \\
\mathbf{9}^{\text {th }} \text { week }(\mathbf{g})\end{array}$ & $\begin{array}{l}\text { Body weight at } \\
\mathbf{1 2}^{\text {th }} \text { week }(\mathbf{g})\end{array}$ \\
\hline Control & $37.2 \pm 0.37$ & $39.4 \pm 0.51$ & $42 \pm 0.45$ & $44.8 \pm 0.58$ & $47.4 \pm 0.51$ \\
\hline BPA 50 mg & $38.2 \pm 0.58^{\mathrm{NS}}$ & $41.4 \pm 0.87^{\mathrm{NS}}$ & $44.4 \pm 0.51^{* *}$ & $46.6 \pm 0.75^{\mathrm{NS}}$ & $50 \pm 0.63^{* *}$ \\
\hline BPA 100 mg & $38.4 \pm 0.51^{\mathrm{NS}}$ & $42.6 \pm 0.93^{*}$ & $46.2 \pm 0.97^{* *}$ & $48.8 \pm 0.86^{* *}$ & $51.8 \pm 0.80^{* *}$ \\
\hline
\end{tabular}

$* *=$ Significant at $1 \%$ level $(\mathrm{p}<0.01), *=$ Significant at $5 \%$ level $(\mathrm{p}<0.05), \mathrm{NS}=$ Not significant $(\mathrm{p}>0.05)$ 
Table 2. Effect of two different doses of BPA on hematological parameters in mice.

\begin{tabular}{|l|l|l|l|}
\hline Parameters & Control & BPA 50 mg & BPA 100 mg \\
\hline $\mathrm{Hb}(\mathrm{gm} \%)$ & $8.44 \pm 0.12$ & $8.04 \pm 0.17^{\mathrm{NS}}$ & $7.48 \pm 0.10^{* *}$ \\
\hline TEC $\left(\mathrm{million} / \mathrm{mm}^{3}\right)$ & $7.60 \pm 0.16$ & $7.33 \pm 0.07^{\mathrm{NS}}$ & $7.24 \pm 0.04^{*}$ \\
\hline $\mathrm{PCV}(\%)$ & $26.20 \pm 1.39$ & $25.00 \pm 1.14^{\mathrm{NS}}$ & $23.40 \pm 0.51^{* *}$ \\
\hline $\mathrm{MCV}(\mathrm{fl})$ & $34.44 \pm 1.52$ & $34.08 \pm 1.22^{\mathrm{NS}}$ & $32.34 \pm 0.74^{\mathrm{NS}}$ \\
\hline MCHC $(\%)$ & $32.48 \pm 1.27$ & $32.30 \pm 0.77^{\mathrm{NS}}$ & $32.02 \pm 0.80^{\mathrm{NS}}$ \\
\hline MCH $(\mathrm{pg})$ & $11.11 \pm 0.18$ & $10.97 \pm 0.13^{\mathrm{NS}}$ & $10.34 \pm 0.09^{* *}$ \\
\hline
\end{tabular}

$* *=$ Significant at $1 \%$ level $(\mathrm{p}<0.01), *=$ Significant at $5 \%$ level $(\mathrm{p}<0.05), \mathrm{NS}=$ Not significant $(\mathrm{p}>0.05)$
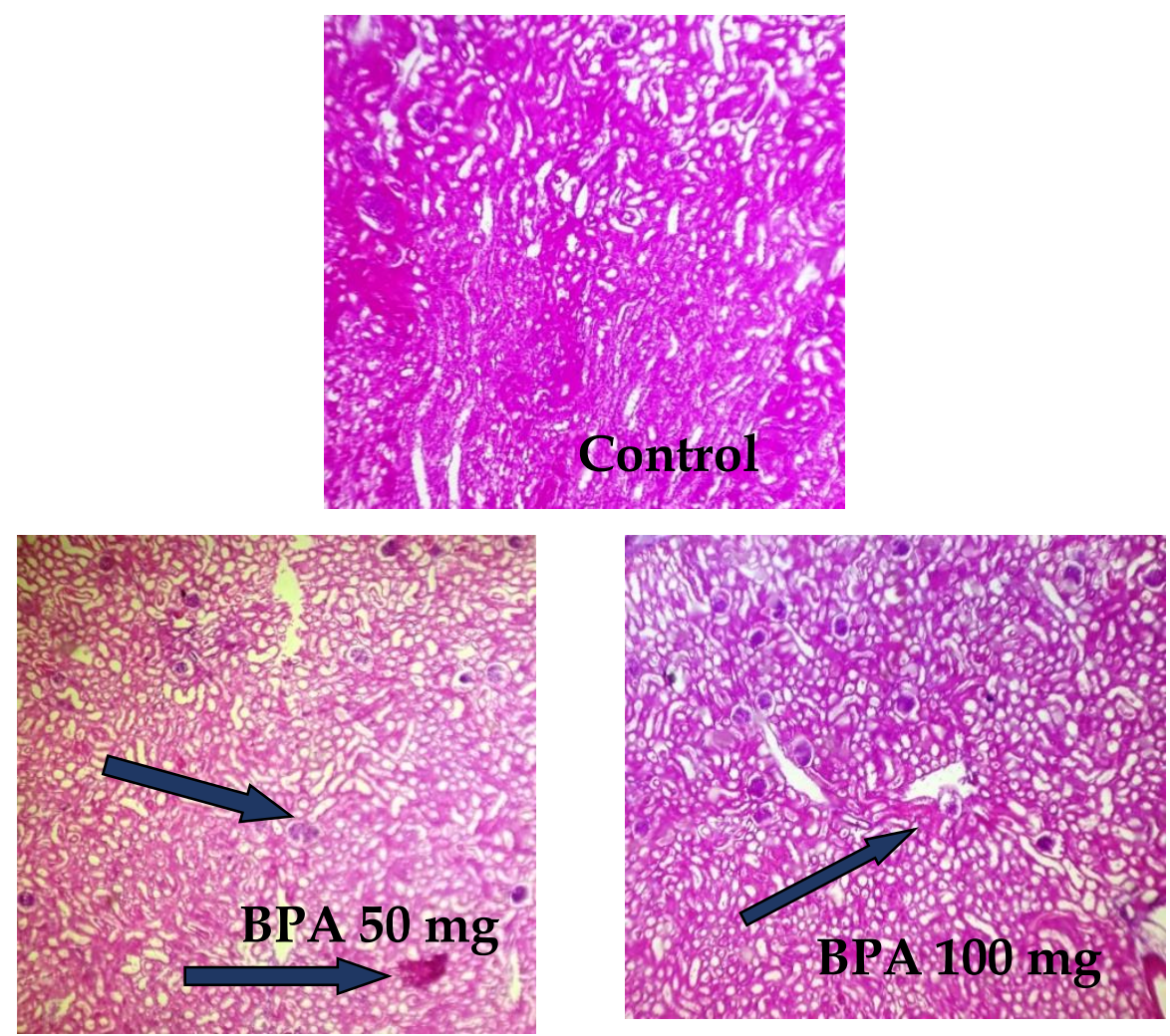

Figure 1. Photomicrograph (10X) of histopathological sections of kidney tissues of different group of mice at $12^{\text {th }}$ week of study.

\section{Conclusions}

Bisphenol-A (BPA) widely used in plastic industry is an estrogenic environmental pollutant that may induce many hazardous effects. Wildlife, human and aquatic animals are easily exposed to BPA due to ubiquitous usage of plastic products. The research findings suggest that exposure to BPA is a risk factor for development of obesity, anemia and renal disorders due to increase in body weight gain, decrease in TEC, $\mathrm{Hb}$ and PCV values and loss of lining epithelium cells of the renal tubules respectively. Data obtained from this work may act as a research tract for filling information gaps in regarding to BPA associated health injuries, primarily in developing countries. However, further study is required to find out the exact mechanism to lower the health hazards associated with BPA.

\section{Acknowledgements}

The authors thank the authority of Department of Physiology, Bangladesh Agricultural University and Department of Pathology, Mymensingh Medical College for analysis of hematological parameters and histopathological studies of kidney, respectively. This research work was supported by the NST fellowship of Bangladesh for MS degree to the first author of this article (Grant No. 2091/311/2017-2018).

\section{Conflict of interest}

None to declare. 


\section{References}

Ahmed WMS, WA Moselhy and TM Nabil, 2015. Bisphenol-A toxicity in adult male rats: Hematological, biochemical and histopathological approach. Glob. Vet., 14: 228-238.

Alonso-Magdalena P, S Morimoto, C Ripoll, E Fuentes and A Nadal, 2006. The estrogenic effect of bisphenolA disrupts the pancreatic $\beta$-cell function in vivo and induces insulin resistance. Environ. Health Perspect., 114: 106-112.

Azimi AS, B Lotfi, M Soleimani-Mehranjani, M Mahdiyeh, SMA Shariatzadeh, E Shojafar and A Khanipuor, 2013. The effect of bisphenol-A on osteogenic activity and morphology of rat bone marrow mesenchymal stem cells in vitro. Cell J., 15: 32-33.

Banchroft J, A Stevens and D Turner, 1996. Theory and practice of histological techniques churchillivingstone. New York, London, San Francisco, Tokyo.

El-Missiry MA, AI Othman, MA Al-Abdan and AA El-Sayed, 2014. Melatonin ameliorates oxidative stress, modulates death receptor pathway proteins, and protects the rat cerebrum against Bisphenol-A-induced apoptosis. J. Neurol. Sci., 347: 251-256.

Fang X, S Cao and R Liu, 2011. Interaction of Bisphenol A with bovine hemoglobin using spectroscopic and molecular modeling methods. Appl. Spectrosc., 65: 1250-1253.

Geetharathan T and P Josthna, 2016. The sensitivity of liver, kidney and ovaries of pregnant rats to oxidative stress induced by bisphenol-A. Int. j. adv. res., 4: 1589-1596.

Ghai CL, 2013. A Textbook of Practical Physiology. Jaypee Brothers Medical Publishers (p) Ltd: New Delhi, India.

Greiner E, T Kaelin and K Nakamura, 2007. Bisphenol-A. CEH Report by SRI Consulting. Environ. Res., 103: 9-20.

Hassan ZK, MA Elobeid, P Virk, SA Omer, M El-Amin, MH Daghestani and EM Al-Olayan, 2012. BisphenolA induces hepatotoxicity through oxidative stress in rat model. Oxid. Med. Cell. Longev., 2012: 1-6.

Hernandez-Rodriguez G, M Zumbado, OP Luzardo, JG Monterde, A Blanco and LD Boada, 2007. Multigenerational study of the hepatic effects exerted by the consumption of Haniokanonylphenol and 4octylphenol contaminated drinking water in Sprague- Dawley rats. Environ. Toxicol. Pharmacol., 23: 73-81.

Korkmaz A, MA Ahbab, D Kolankaya and Barlas, 2010. Influence of vitamin C on bisphenol-A, nonyphenol and octylphenol induced oxidative damages in liver of male rats. Food Chem. Toxicol., 48: 2865-2871.

Michalowicz J, 2014. Bisphenol-A-Sources, toxicity and biotransformation. Environ. Toxicol. Pharmacol., 37: 738-758.

Miyawaki J, K Sakayama, H Kato, H Yamamoto and H Masuno, 2007. Perinatal and postnatal exposure to bisphenol-A increases adipose tissue mass and serum cholesterol level in mice. J. Atheroscler. Thromb., 14: 245-252.

Nakagawa Y and S Tayama, 2000. Metabolism and cytotoxicity of bisphenol-A and other bisphenols in isolated rat hepatocytes. Arch. Toxicol., 74: 99-105.

Newbold RR, E Padilla-Banks, WN Jefferson and JJ Heindel, 2008. Effects of endocrine disruptors on obesity. Int. J. Androl., 31: 201-207.

Oehlmann J, U Schulte-Oehlmann, W Kloas, O Jagnytsch, I Lutz, KO Kusk, L Wollenberger, EM Santos, GC Paull, KJ Van Look and CR Tyler, 2009. A critical analysis of the biological impacts of plasticizers on wildlife. Philos. Trans. R. Sci., 364: 2047-2062.

Petteri N, 2002. Effects of bisphenol-A and phytosterols on the European polecat (Mustelaputorius) and the field vole (Microtusagrestis). Academic Dissertation, Department of Medicine, University of Helsinki for public examination in Auditorium, ISBN 952-91-4484-9 (Print), ISBN 952-10-0533-5.

Rahimi O, F Farokhi, SMB Khojasteh and SA Ozi, 2015. The effect of bisphenol-A on serum parameters and morphology of kidney's tissue. BFAIJ., 7: 79-90.

Roig B, A Cadiere, S Bressieux, S Biau, S Faure and PD Barbara, 2014. Environmental concentration of nonylphenol alters the development of urogenital and visceral organs in avain model. Environ. Int., 62: 7885.

Rubin BS, 2011. Bisphenol-A: An endocrine disruptor with widespread exposure and multiple effects. J. Steroid. Biochem., 127: 27- 34.

Rubin BS and AM Soto, 2009. Bisphenol A: Perinatal exposure and body weight. Mol. Cell. Endocrinol., 304: 55-62.

Samie HAA, SA Nassar and Y Hussein, 2017. Ameliorative potential of selenium against bisphenol-A induced hepatotoxicity in rats. Egypt. J. Hosp. Med., 67: 444- 454. 
Sangai NP, RJ Verma and MH Trivedi, 2012. Testing the efficacy of quercetin in mitigating bisphenol-A toxicity in liver and kidney of mice. Toxicol. Ind. Health., 30: 581-97.

Uluta OK, N Yldz, E Durmaz, MA Ahbab, N Barlas and Ã Çok, 2011. An in vivo assessment of the genotoxic potential of bisphenol -A and 4-tert-octylphenol in rats. Arch. Toxicol., 85: 995-1001.

vomSaal FS, BT Akingbemi, SM Belcher, LS Birnbaum, DA Crain, M Eriksen, F Farabollini, LJ Guillette Jr, R Hauser, JJ Heindel, SM Ho, PA Hunt, T Iguchi, S Jobling, J Kanno, RA Keri, KE Knudsen, H Laufer, GA LeBlanc, M Marcus, JA McLachlan, JP Myers, A Nadal, RR Newbold, N Olea, GS Prins, CA Richter, BS Rubin, C Sonnenschein, AM Soto, CE Talsness, JG Vandenbergh, LN Vandenberg, DR Walser-Kuntz, CS Watson, WV Welshons, Y Wetherill and RT Zoeller, 2007. Chapel Hill bisphenol-A expert panel consensus statement: integration of mechanisms, effects in animals and potential to impact human health at current levels of exposure. Reprod. Toxicol., 24: 131-138.

Yamasaki K and H Okuda, 2012. Comparison of endocrine-mediated effects of two bisphenol - A related compounds, 2,2-bis (4-cyanatophyenyl) propane and 4,4' cyclohexylidenebisphenol, based on subacute oral toxicity studies using rats. Toxicol. Lett., 208: 162- 167.

Yildiz N and N Barlas, 2013. Hepatic and renal functions in growing male rats after bisphenol $\mathrm{A}$ and octylphenol exposure. Hum. Exp. Toxicol., 32: 675-686. 